\title{
Respon Mahasiswa terhadap Perkuliahan Berbasis Projek dalam Upaya Penguatan Program Kewirausahaan
}

\author{
Aan Hasanah ${ }^{1}$, Dadang Juandi ${ }^{1, *}$, Cece Kustiawan ${ }^{1}$ \\ ${ }^{1}$ Universitas Pendidikan Indonesia \\ *aanhasanah@upi.edu
}

\begin{tabular}{|l|l|l|l|}
\hline Received : 27-10-2021 & Revised: $13-12-2021$ & Accepted: $18-12-2021$ & Published: $21-12-2021$ \\
\hline
\end{tabular}

\begin{abstract}
ABSTRAK
Studi ini bertujuan untuk mengetahui respon mahasiswa terhadap perkuliahan kewirausahaan berbasis projek. Metode deskriptif kuantitatif digunakan pada data hasil survey terhadap mahasiswa yang pernah mengikuti perkuliahan kewirausahaan di FPMIPA UPI pada tahun 2021 yang terdiri dari 35 responden laki-laki dan perempuan, diambil dengan cara penyampelaan bertahap (multi-stage sampling). Instrumen berupa angket terdiri dari 50 pernyataan, 19 pernyataan digunakan untuk mengungkap respon yang berkaitan dengan aspek proses perkuliahan dan 31 pernyataan digunakan untuk mengungap respon terkait aspek sikap mahasiswa. Hasil studi menunjukkan bahwa secara umum respon mahasiswa dalam aspek proses dan aspek sikap terhadap perkuliahan kewirausahaan berbasis projek berada dalam kategori memuaskan. Mahasiswa laki-laki dan perempuan memberikan respon dalam kategori yang tidak berbeda. Respon terhadap pernyataan yang berkaitan dengan proses perkuliahan berbasis projek adalah sangat memuaskan, dan lebih baik daripada respon terhadap pernyataan yang berkaitan dengan sikap yang berada dalam kategori memuaskan. Respon paling buruk diberikan terhadap pernyataan yang berkaitan dengan keberlanjutan projek kewirausahaan. Respon terbaik diberikan pada pernyataan bahwa pengembangan kewirausahaan dalam dunia pendidikan memiliki banyak tantangan.
\end{abstract}

Kata Kunci : Kewirausahaan, projek, respon, proses, sikap

\section{ABSTRACT}

This study aims to find out students' responses toward project-based entrepreneurship lecture. The quantitative descriptive method was used in the results of the data survey on students who had attended lecture at FPMIPA UPI in 2021, which was consisted of 35 male and female respondents, taken by means of multi-stage sampling. The instrument of study was a questionnaire involving 50 statements, 19 statements to reveal responses related to the lecture process, and 31 statements to reveal responses related to student attitudes. The results of study showed that in general, students response in the process and attitude aspects toward project-based entrepreneurship lecture were in satisfactory category. Male and female students gave responses in no different categories. The students' responses to the statement related to project-based learning aspect were very satisfying and it was better than the students'responses to attitude that were in the satisfactory category. The worst response was given to statements related to suistainable entrepreneurial projects. The best response was given to the statement that the development of entrepreneurship in education has many challenges.

Keywords: Entrepreneurship, project, response, process, attitude 


\section{PENDAHULUAN}

Memperhatikan data Global Enterpreneurship Index 2018, dari 137 negara, Indonesia berada di peringkat 94 dalam hal kewirausahaan. Posisi tersebut masih tertinggal dibandingkan beberapa negara di Asia Tenggara lainnya. Sebab, Vietnam berada di urutan ke 87, Filipina di posisi 76, Thailand di 71, Malaysia peringkat 58, Brunei Darussalam di 53, serta Singapuran berada di urutan ke 27. Saat ini, perekonomian Indonesia 99\% digerakkan oleh usaha kecil, mikro dan ultra mikro, sayangnya rasio jumlah wirausahawan terhadap total populasi di Indonesia masih ketinggalan dibandingkan negara ASEAN lainnya, misalnya Singapura sudah 7\%, Malaysia sudah 6\%, Thailand sudah $5 \%$, sedangkan Indonesia masih di bawah 3\%. Kondisi tersebut tidak akan berubah bahkan bisa menjadi lebih memprihatinkan jika tidak ada upaya dari berbagai pihak untuk memperbaikinya, salah satunya dengan melibatkan para mahasiswa dalam kegiatan berbasis kewirausahaan.

Melambatnya ekonomi Indonesia mengakibatkan jumlah pengangguran dalam negeri bertambah. Dalam setahun terakhir, persentase pekerja setengah penganggur dan persentase pekerja paruh waktu naik masing-masing sebesar 3,77 persen poin dan 3,42 persen poin. Pada tahun 2021, terdapat pengangguran tambahan sebesar 1,1 juta orang sebagai akibat Covid-19 dan sekitar 2,6 juta orang angkatan kerja baru yang tidak terserap sehingga tambahan pengangguran totalnya tahun 2021 sebesar 3,6 juta orang (Sumber: Laporan BPS). Ditinjau dari tingkat pendidikan, lulusan universitas tingkat penganggurannya 7,36 \%. Kondisi lulusan Perguruan Tinggi seperti di atas sungguh memprihatinkan di tengah tuntutan era globalisasi dengan persaingan global dan pasar bebas, lapangan kerja yang semakin kompetitif, sementara itu banyak lulusan PT yang belum siap bekerja dan menunggu diberi pekerjaan. Kenyatan tersebut menunjukkan semakin perlunya PT untuk membentuk sumberdaya manusia berkualitas yang mempunyai keunggulan kompetitif, komparatif serta penciptaan lapangan kerja sendiri (berwirausaha). Dengan demikian, pendidikan kewirausahaan adalah suatu hal yang dibutuhkan bagi para peserta didik dan masyarakat yang bukan hanya menumbuhkan semangat, melainkan membangun konsep berfikir dan mendorong secara praktis kemampuan kewirausahaan pada lulusannya.

Dirjen Pendidikan Perguruan Tinggi (DIKTI) sebagai lembaga yang menaungi pendidikan tingkat universitas memberlakukan mata kuliah kewirausahaan yang harus diikuti oleh mahasiswa semua jurusan bidang studi. Di samping itu, DIKTI juga 
menyediakan wadah bagi para mahasiswa untuk mengembangkan kreatifitas kewirausahaan diantaranya melalui Program Mahasiswa Wirausaha (PMW) dan Program Kreativitas Mahasiswa Kewirausahaan (PKM-K) yang merupakan program pengembangan keterampilan mahasiswa dalam berwirausaha berorientasi pada laba (profit) di mana program tersebut akan menjadi salah satu modal dasar mahasiswa dalam berwirausaha dan memasuki pasar. Namun, sangat disayangkan minat mahasiswa pada umumnya masih rendah, mungkin hal ini berkaitan dengan pelaksanaan perkuliahan kewirausahaan. Kelemahan dalam pendidikan kewirausahaan di perguruan tinggi selama ini diantaranya adalah kurikulum atau materi yang diajarkan dalam mata kuliah kewirausahaan baru sebatas teori di dalam kelas. Dengan kata lain materi yang diajarkan dalam mata kuliah kewirausahaan tersebut belum mampu menumbuhkan, menanamkan, serta menguatkan nilai-nilai kewirausahaan dalam diri mahasiswa yang tidak mungkin dapat dipenuhi hanya secara teori (Kasih, 2013). Rancangan kurikulum kewirausahaan (mata kuliah/materi) sebaiknya mengambarkan nilai-nilai kewirausahaan yang harus diberikan kepada mahasiswa untuk menjadi seorang wirausaha yang mempunyai kemampuan untuk melihat dan menilai kesempatan bisnis yang ada, kemudian melakukan inventarisasi dan mengatur sumber daya yang dapat diusahakan serta mengambil tindakan yang tepat untuk meraih keberhasilan dalam mengisi kesempatan bisnis tersebut.

Meredith (1993) menyatakan bahwa profil seorang wirausaha harus memiliki ciriciri dan watak (1) percaya diri, adanya keyakinan terhadap kemampuan diri sendiri sehingga tidak bergantung kepada pihak lain serta bersikap optimis; (2) berorientasi pada tugas dan hasil, yakni memiliki tuntutan atau kebutuhan terhadap prestasi yang tinggi, bekerja keras, ulet, tekun, tabah, energik, dan mempunyai inisiatif yang tinggi; (3) mengambil risiko, dengan pengertian mempunyai keberanian untuk mengambil risiko atas kegagalan usaha, bertanggungjawab serta senang pada kegiatan usaha yang bersifat menantang; (4) tidak mudah puas, yakni selalu berusaha untuk meningkatkan pretasi dan mengadakan penemuan baru serta bertindak sebagai pioner.

Karakteristik wirausaha tersebut menggambarkan bahwa seorang wirausahawan adalah seorang yang kreatif dan inovatif, tangguh, ulet dan mempunyai visi untuk selalu maju dan berkembang. Dengan memiliki karakteristik yang demikian, seseorang yang mempunyai usaha, dapat dikatakan sebagai wirausahawan (entrepreneur). Alberti et al (2004) dalam studinya mengenai pendidikan kewirausahaan yang mengacu pada Vesper (1998) menjelaskan ada empat macam pengetahuan yang berguna bagi wirausaha, yaitu (1) pengetahuan secara umum tentang bisnis, (2) pengetahuan tentang perusahaan, (3) 
pengetahuan khusus tentang peluang bisnis, (4) pengetahuan khusus tentang perusahaan atau usaha. Selain itu, Bygrave (1994) mengajarkan pada mahasiswa tentang proses kewirausahaan, pengenalan peluang, strategi memasuki bisnis, peluang pasar dan pemasaran, pembuatan rencana bisnis yang sukses, proyeksi keuangan, modal usaha, pembiayaan dalam bentuk hutang dan lainnya, bantuan eksternal untuk memulai usaha dan bisnis kecil, hukum dan isu-isu pajak, hak kekayaan intelektual, franchising, harvesting dan ekonomi kewirausahaan. Sehubungan dengan hal ini, menurut Moelyono (2010), kurikulum beroreintasi kreatif dan pembentukan jiwa kewirausahaan, yaitu kurikulum yang mampu untuk: a) membentuk kompetensi agar menjadi individu-individu visioner yang mampu menerima berbagai skenario tantangan, melihat peluang dan berani mengambil risiko, termasuk melatih kemampuan mencerna permasalahan dan mengambil keputusan dengan tepat walaupun tanpa adanya panduan yang cukup; b) memfasilitasi intensifikasi skill, talenta dan kreativitas, serta c) menyeimbangkan program yang bersifat hard skill dengan soft skill. Untuk mencapai dua keterampilan tersebut peneliti telah mengembangan model perkuliahan kewirausahaan berbasis proyek.

Konsep pembelajaran berbasis proyek (Project Based Learning, disingkat PJBL), memprioritaskan konsep 4C yaitu collaboration, communication, creativity, and critical thinking; Depdiknas (2014). Menurut Doppelt (2005) PJBL berkaitan dengan kehidupan nyata dengan menerapkan konsep Creative Design Prosess (CDP) yang terdiri dari enam tahap yaitu: merancang tujuan (Design Purpose), mengajukan pertanyaan/ inquiry (Field of Inquiry), mengajukan alternatif solusi (Solution Alternatives), memilih solusi (Choosing the Preferred Solution), melaksanakan kegiatan (Operation Steps), evaluasi (Evaluation). Margendoller (2006) PJBL dengan tahapan: Perencanaan, Pelaksanaan proyek, Penyelidikan terbimbing dan Pembuatan produk, serta Kesimpulan proyek. Kegiatan perencanaan meliputi: identifikasi masalah, menemukan dan memecahkan masalah, dan melakukan perencanaan. Tahap pelaksanaan meliputi pembimbingan dalam penyelesaian tugas, dalam melakukan pengujian produk, presentasi antar kelompok. Tahap evaluasi meliputi penilaian proses dan produk meliputi: kemajuan belajar proyek, proses aktual dari pemecahan masalah, kemajuan kinerja tim dan individual. Sedangkan penilaian produk dapat dilihat dari hasil kerja dan presentasi, tugas-tugas non tulis, laporan proyek.

Pembelajaran berbasis projek dalam penelitian ini mengedepankan stimulus permasalahan di awal perkuliahan. Stimulus permasalahan menggunakan isu-isu yang sedang trend saat ini baik isu global ataupun lokal. Melalui stimulus tersebut para mahasiswa diberi tugas berupa proyek yang harus dipecahkan bersama tim kerja dan berkolaborasi 
dengan dosen. Selama satu semester mahasiswa disuguhi dengan empat isu global dan lokal terkait berbagai jenis wirausaha edupreneur, techerpreneur, technopreneur, dan sociopreneur. Kegiatan di dalam pengerjaan proyek meliputi: (1) Identifikasi masalah global atau lokal; (2) Merencanakan alternatif solusi masalah dan analisis peluang usaha; (3) Pemilihan pengentasan masalah yang berpotensi profit dan desain awal prototype; (4) Uji prototype wirausaha dan rencana pemasaran; (5) Evaluasi dan penulisan proposal. Produk pembelajaran berbasis proyek ini adalah proposal kewirausahaan yang disusun oleh mahasiswa secara berkelompok. Salah satu tujuan perkuliahan kewirausahaan berbasis proyek adalah mendeskripsikan respon mahasiswa terhadap proses perkuliahan kewirausahaan berbasis projek, yang selanjutnya menjadi fokus bahasan pada artikel ini.

\section{METODE PENELITIAN}

Metode yang digunakan dalam penelitian ini deskriptif kuantitatif berbasis survey terbatas melalui skala pendapat yang disebarkan dalam bentuk google formulir selama 2 minggu. Populasi penelitian adalah mahasiswa UPI yang sudah pernah mengikuti perkuliahan berbasis projek dlam satu tahun terakhir sebanyak kurang lebih 100 mahasiswa, sedangkan sampel yang terlib at adalah terdiri dari 35 mahasiswa dari program studi Pendidikan Matematika UPI. Metode sampling yang digunakan adalah multi stage sampling, tahap pertama diperoleh 24 responden, tahap kedua diperoleh 11 rseponden dan tahap ketiga diperoleh 3 responden, sehingga total sampel adalahh 35 responden.

Penelitian dilakukan selama 1 semester pada pada taun ajaran 2020/2021. Instrumen untuk menjaring respon mahasiswa 50 pernyataan positif dan negatif berbentuk angket model Likert dengan 4 skala (SS, S, TS, STS), angket disusun berdasarkan beberapa indikator diantaranya proses pembelajaran, keyakinan, dan orientasi.

\section{HASIL DAN PEMBAHASAN}

Sesuai dengan tujuan penelitian, selanjutnya dijelaskan bagaimana respon mahasiswa terhadap pembelajaran berbasis projek pada perkuliahan kewirausahaan. 


\section{Respon Mahasiswa Secara Keseluruhan.}

Berdasarkan hasil penelaahan terhadap jawaban dari 35 responden untuk 50 item pernyataan, diperoleh hasil pada tabel 1 .

Tabel 1. Deskripsi Statistik

\begin{tabular}{lll}
\hline $\mathrm{N}$ & 35 \\
\hline Mean & 115.8571 \\
\hline Std. Deviation & 22.24878 \\
\hline Minimum & 79.00 \\
\hline Maximum & & 162.00 \\
\hline Percentiles & 25 & 97.0000 \\
\hline & 50 & 112.0000 \\
& 75 & 137.0000
\end{tabular}

Dari Tabel 1 diperoleh repon terendah adalah 79 berada 19 point di atas skor minimum ideal (50), yaitu jika responden hanya mendapat skor 1 untuk setiap item dari 50 pernyataan, dan respon tertinggi adalah 162, berada 38 di bawah skor maksimum (200), yaitu jika responden mendapat skor 4 untuk setiap item dari 50 pernyataan. Deskriptif di atas selanjutnya dibuat kategori tingkat respon dengan menggunaka nilai persentil, sebagai berikut.

Tabel 2. Pengategorian Tingkatan Respon

\begin{tabular}{lcl}
\hline No & Rentang Nilai & Kategori Tingkat Respon \\
\hline 1 & $X<P 25$ & Kurang Baik \\
\hline 2 & $P 25 \leq X \leq P 75$ & Baik \\
\hline 3 & $X \geq P 75$ & Sangat Baik
\end{tabular}

Tabel 3. Deskripsi Respon Keseluruhan

\begin{tabular}{ccc}
\hline Kategori & Frequensi & Persentase \\
\hline Kurang Baik & 8 & 22,9 \\
\hline Baik & 15 & 42,9 \\
\hline Sangat Baik & 12 & 34,3 \\
\hline Total & 15 & 100
\end{tabular}

Berdasarkan Tabel 3, dapat diinterpretasikan bahwa dari 35 responden hanya 8 $(22.9 \%)$ responden yang merespon nya kurang baik terhadap pembelajaran kewirausahaan berbasis projek, sedangkan mayoritas merespon baik dan sangat baik (77,1\%). Angka 77,1 
$\%$ dianggap memadai untuk menyimpulkan bahwa respon mahasiswa terhadap pembelajran berbasis projek dapat dikatakan memuaskan.

\section{Respon Berdasarkan Gender}

Analisis selanjutnya dilihat berdasarkan kategori gender, hasilnya disajikan dalam Tabel 4.

Tabel 4. Tingkatan Respon Berdasarkan Gender

\begin{tabular}{|c|c|c|c|c|c|}
\hline & & \multicolumn{3}{|c|}{ TINGKATAN RESPON } & \multirow[t]{2}{*}{ Total } \\
\hline & & 1 & 2 & 3 & \\
\hline G LAKI-LAKI & KUANTITAS & 2 & 4 & 3 & 9 \\
\hline \multirow[t]{2}{*}{$\mathbf{E}$} & $\%$ DALAM GENDER & $22.2 \%$ & $44.4 \%$ & $33.3 \%$ & $100.0 \%$ \\
\hline & $\%$ DARI TOTAL & $5.7 \%$ & $11.4 \%$ & $8.6 \%$ & $25.7 \%$ \\
\hline \multirow[t]{3}{*}{$\mathbf{N}$ PEREMPUAN } & KUANTITAS & 6 & 11 & 9 & 26 \\
\hline & $\%$ DALAM GENDER & $23.1 \%$ & $42.3 \%$ & $34.6 \%$ & $100.0 \%$ \\
\hline & $\%$ DARI TOTAL & $17.1 \%$ & $31.4 \%$ & $25.7 \%$ & $74.3 \%$ \\
\hline \multicolumn{6}{|l|}{$\mathbf{E}$} \\
\hline \multicolumn{6}{|l|}{$\mathbf{R}$} \\
\hline \multirow[t]{2}{*}{ Total } & KUANTITAS & 8 & 15 & 12 & 35 \\
\hline & $\%$ DARI TOTAL & $22.9 \%$ & $42.9 \%$ & $34.3 \%$ & $100.0 \%$ \\
\hline
\end{tabular}

Dari Tabel 4, diperoleh gambaran bahwa hanya 22,2 \% dari semua laki-laki yang merespon kurang baik, sedangkan 77,8\% merespon baik dan sangat baik. Dari semua perempuan terdapat $23,1 \%$ yang merespon kurang baik, dan $76,9 \%$ merespon baik dan sangat baik. Jadi dalam hal ini baik laki-laki maupun perempuan mmberikan tingkatan respon kurang baik yang seimbang, demikian juga respon baik, dimana selisih terbesarnya kurang dari $2 \%$, yaitu 44,4-42,9. Jika dilhat secara total, repon kurang baik hanya sekitar $22,9 \%$ yang berarti bahwa lebih dari $77 \%$ laki-laki atau pun perempuan memberikan respon yang baik dan sanagat baik. Hasil ini menunjukkan bahwa respon mahasiswa terhadap perkuliahan berbasis projek dalam kategori memuaskan.

\section{Respon Berdasarkan Aspek Proses dan Aspek Sikap}

Pernyataan dalam survey dibagi dalam dua aspek, yaitu saspek proses pembelajaran, dan aspek sikap terhadap kewirausahaan. Banyaknya pernyataan utnuk mengungkap respon terhadap proses pembelajaran berbasis projek adalah 19 item (38\%) dan sisanya sebanyak 
31 item $(62 \%)$ digunakan untuk mengungkap sikap terhadap kewirausahaan melalui pembelajaran berbasis projek. Pembagian kategori dapat dilihat pada Table 5.

Tabel 5. Deskripsi Aspek Respon

\begin{tabular}{lrr}
\hline Aspek & Frekuensi & \multicolumn{1}{c}{ Persentase } \\
\hline PROSES & 19 & 38.0 \\
\hline SIKAP & 31 & 62.0 \\
\hline TOTAL & 50 & 100.0
\end{tabular}

Selanjutnya untuk menelaah respon mahasiswa dilihat dari aspek proses dan aspek sikap dapat dilihat dari Table 6.

Tabel 6. Deskrisi Respon Berdasarkan Aspek

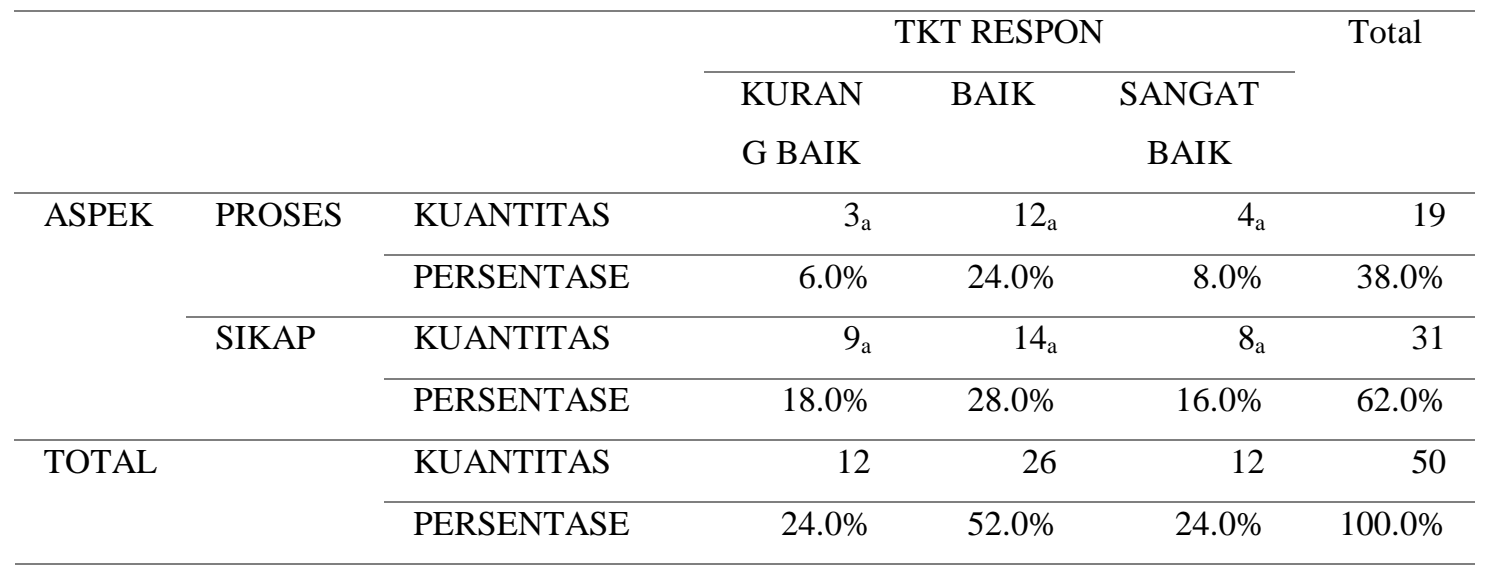

Dari Tabel 6 nampak bahwa persentase respon kurang baik terhadap aspek proses adalah 6\%, sedangkan terhadap aspek sikap adalah 18\%. Ini menggambarkan bahwa dari aspek proses pembelajaran berbasis projek mahasiswa lebih banyak merespon baik daripada terhadap aspek sikap dalam kewirausahaan, dengan kata lain respon mahasswa terhadap pernyataan yang berkaitan dengan aspek proses adalah sangat memuaskan, sedangkan terhadap pernyataan yang berkaitan dengan sikap adalah memuaskan.

\section{Respon terhadap Pernyataan}

Deskripsi selanjutnya adalah respon terhadap 50 pernyataan yang diberikan kepada 35 responden, sebagai berikut. 
Tabel 7. Deskripsi Statistik

\begin{tabular}{lll}
\hline $\mathrm{N}$ & 50 \\
\hline Mean & & 92.3200 \\
\hline Std. Deviation & & 21.90186 \\
& & \\
\hline Minimum & & 50.00 \\
\hline Maximum & & 132.00 \\
\hline Percentiles & 25 & 76.7500 \\
\cline { 2 - 3 } & 50 & 94.0000 \\
\cline { 2 - 3 } & 75 & 108.2500
\end{tabular}

Dari Tabel 7, dapat diinterpretasikan bahwa nilai minimum skor adalah 50, lebih besar dari nilai minimum ideal sebesar 35, yaitu jika semua responden mengatakan sangat tidak setuju terhadap pernyataan positif dan sangat setuju terhadap pernyataan negatif untuk 50 pernyataan yang diberikan. Nilai maksimum adalah 132, sedikit berada dibawah 140 sebagai skor ideal maksimal, yaitu jika semua responden memberikan nilai 4 atau sangat untuk pernyataan positif dan memberikan nilai 1 atau sangat tidak setuju terhadap peryataan negative, sehingga untuk 50 pernyataan memberikan skor maksima ideal 140.

Selanjutnya, dengan menggunkan nilai persentil ke 25 dan ke 75, respon dari 35 responden terhadap 50 item pernyataan yang diberikan, diperoleh sebagai berikut.

Tabel 8. Deskripsi Respon terhadap Seluruh Pernyataan

\begin{tabular}{ccc}
\hline Kategori & Frekuensi & Persentase \\
\hline KURANG BAIK & 12 & 24.0 \\
\hline BAIK & 26 & 52.0 \\
\hline SANGAT BAIK & 12 & 24.0 \\
\hline Total & 50 & 100.0 \\
\hline
\end{tabular}

Dari Tabel 8 memperlihatkan bahwa dari 50 item pernyataan yang diberikan, terdapat 12 item (24\%) yang direspon kurang baik, 26 pernyataan (52\%) yang direspon baik, dan 12 pernyataan (24\%) ddirespon sangat baik, sehingga secara umum diperoleh bahwa seayak $76 \%$ pernyataan mendapat respon yang baik dan sangat baik. Nilai $76 \%$ merupakan batasan yang cukup untuk menyimpulkan bahwa secara keseluruhan, responden merespon baik dan sangat baik terhadap proses pembelajaran berbasis projek dalam perkuliahan kewirausahaan dan juga bersikap baik terhadap aspek-aspek kewirausahaan, maka dapat 
disimpulkan bahwa respon terhadap pernyataan-pernyataan dapat berada dalam kategori memuaskan.

\section{Respon kurang baik terhadap beberapa pernyataan}

Berdasarkan analisis sebelumnya terdapat rrespon kurang baik terhadap pernyataaan dalam aspek proses maupun aspek sikap. Oleh karena itu akan dideskripsikan beberapa pernyataan yang medapat respon kurang baik tersebut. Pernyataan yang didalami adalah yang mendapat skor dibawah 76 sebagai quartil 1 atau persentil 25 . Berikut daftar pernyataan yang direspon kurang baik.

Tabel 9. Pernyataan dengan Respon Terburuk

\begin{tabular}{llc}
\hline No & Pernyataan & Skor \\
\hline 34 & $\begin{array}{l}\text { Prilaku Entrepreneursip dalam bidang pendidikan merupakan tantangan } \\
\text { baru bagi kaum milenial }\end{array}$ & 72 \\
\hline 35 & $\begin{array}{l}\text { Kaum milenial banyak yang tertarik dalam pengembangan Entrepreneursip } \\
\text { dalam bidang pendidikan }\end{array}$ & 57 \\
\hline 37 & $\begin{array}{l}\text { Kaum milenial banyak menggunakan medsos untuk hiburan daripada untuk } \\
\text { kegiatan Entrepreneursip }\end{array}$ & 69 \\
\hline 41 & \begin{tabular}{l} 
Saya melanjutkan pengembangan tugas projek Entrepreneursip \\
\hline 50
\end{tabular} & $\begin{array}{l}\text { Saya membutuhkan bahan ajar yang dapat diakses kapan saja untuk } \\
\text { menyelesaikan tugas projek. }\end{array}$ \\
\hline
\end{tabular}

Dari Tabel 9 terlihat bahwa yang paling buruk respon nya terhadap penyataan nomor 35 dan 41, dimana skor yang peroleh adalah 50 dan merupakan skor terendah, hal ini mengisyaratkan mahasiswa masih kurang termotivasi dalam mengembangkan tugas projek. Temuan lain yanga sangat menarik adalah respon terhadap pernyataan nomor 37 yang menunjukkan belum opptimalnya penggunaan medsos dalam kegiatan eterprenership, sementara kegitan enttrepreneursip dalam bidang pendidikan responnya masih belum baik mungki hal ini sangat berkaitan dengan masih butuhnya bahan ajar yang dapat mendudkung kegiatan projek.

Walaupun respon kurang baik ditampilkan melalui beberapa pernyataan, ternyata respon yang baik bahkan sangat baik lebih banyak. berikut ini disajikan pernyataan yang direspon sangat baik, yaitu pernyatan yang mendapat skor lebih dari 108 . 
Tabel 10. Pernyataan dengan Respon Terbaik

\begin{tabular}{clc}
\hline No & \multicolumn{1}{c}{ PERNYATAAN } & SKOR \\
\hline 2 & Pembelajaran berbasis projek mendorong berpikir kreatif & 115 \\
\hline 3 & Perkuliahan berbasis projek menantang untuk berinovasi dalam kewirausahaan & 117 \\
\hline 11 & Bahan ajar berbasis projek mendorong mahasiswa focus belajar & 116 \\
\hline 22 & $\begin{array}{l}\text { Pengembangan Entrepreneursip dalam dunia pendidikan memiliki banyak } \\
\text { tantangan }\end{array}$ & 126 \\
\hline 26 & Modal utama dalam membangun entrepreneursip adalah motivasi dan keyakinan & 114 \\
\hline 28 & $\begin{array}{l}\text { Kecerdasan intrapersonal adalah factor penting dalam mengembangkan } \\
\text { Entrepreneursip }\end{array}$ & 124 \\
\hline 30 & Modal finansial bukanlah segalanya untuk membangun Entrepreneursip & 130 \\
\hline 47 & Saya aktif mencari informasi untuk menunjang keberhasilan tugas projek & 110
\end{tabular}

Dari Tabel 10 terlihat bahwa pernyataan yang paling tinggi responnya adalah, "Modal finansial bukanlah segalanya untuk membangun, disusul oleh pernyataan Entrpreneursip, disusul oleh pernyataan "Pengembangan Entrepreneursip dalam dunia pendidikan memiliki banyak tantangan", serta pernyataan, "Kecerdasan intrapersonal adalah faktor penting dalam mengembangkan Entrepreneursip." Ketiga pernyataan ini mengandung makna bahwa responden memliki keyakinan yang baik terhadap pembelajaran berbasis projek untuk mengembangkan sikap positif, dan ternyata respon baik terhdap pernyataan tersebut didukung oleh respn lainnya terhadap pernyataan yang menyangkut proses pembelajaran. Seperti tampak pada pernyataan nomor 2, 3, dan 11. Melihat lebih banyak pernyataan yang direspon baik dan lebih baik, menunjukkan bahwa pembelajaran berbasis projek memiliki potensi yang baik dalam mengkatkan kegiatan kewirausahaan mahasiswa.

\section{KESIMPULAN}

Berdasarkan hasil analisis data diperoleh kesimpulan bahwa: 1) secara umum respon mahasiswa terhadap perkuliahan kewirausahaan berbasis projek berada dalam kategori memuaskan; 2) mahasiswa laki-laki mau pun perempuan memberikan respon dalam kategori yang tidak berbeda; 3 ) respon terhadap pernyataan yang berkaitan dengan proses perkuliahan berbasis projek adalah sangat memuaskan, serta lebih baik daripada respon terhadap pernyataan yang berkaitan dengan sikap yang berada dalam kategori memuaskan; 4) respon paling buruk diberikan terhadap pernyataan yang berkaitan dengan keberlanjutan projek 
kewirausahaan; 5) respon terbaik diberikan pada pernyataan bahwa pengembangan

Entrepreneursip dalam dunia pendidikan memiliki banyak tantangan.

\section{REFERENSI}

Badan Pusat Statistik. (2020). Keadaan Keadaan Ketenagakerjaan Indonesia Agustus 2020. Tersedia: https://www.bps.go.id/pressrelease/ Agustus 2020

Borg, W.R., \& Gall, M.D. (1989). Education Research: An Introduction (Fifth ed.). New York: Longman.

Buchholz, R. A., et al, (2005), The Spirit of Entrepreneurship and The Qualities of Moral Decision Making: Toward A Unifying Framework, Journal of Business Ethics, 60:307-315, DOI 10.1007/s10551-005-0137-0.

Crea, E., A., Mc., (2010), Integrating Service-Learning Into an Introduction to Entrepreneurship Course, Journal of Management Education, Vol. 34, Iss.1, pp. $39-61$.

Direktorat Tenaga Kependidikan, Ditjen peningkatan Mutu. (2008). Penulisan Modul. Pendidik dan Tenaga Kependidikan, Departemen Pendidikan Nasional, Jakarta.

Direktorat Jenderal Pendidikan Tinggi. (2009). Pedoman Program Mahasiswa Wirausaha $(P M W)$ Dikti. Jakarta: Direktorat Kelembagaan.

Direktorat Riset dan Pengabdian kepada Masyarakat. (2020). Panduan Penelitian dan Pengabdian kepada Masyarakat di Perguruan Tinggi. Jakarta : Dirjenristekdikti.

Gay, L.R. (1981). Educational Research: Competencies for Analysis and Application. Colombus, OH: Charles E. Merill.

Ilmu Ekonomi. (2016, 6 October). Pengertian dan Tujuan SDGs (Sustainable Development Goals). Retrieved January 6, 2019. From https://www.ilmu-ekonomiid.com/2016/10/pengertian-dan-tujuan-sdgs-sustainable-development-goals.html

Ihsan, M. (2018, 1 November). Bisnis Ingin Moncer, Ikuti SDGs. Retrieved January 6, 2019. From https://www.wartaekonomi.co.id/read201743/bisnis-ingin-moncer-ikutisdgs.html

Jehanzeb. (2013). Training and Development Program and Its Benefits to Employee and Organization: A Conceptual Study, European Journal of Business and Management, Vol. 5, no. 2, pp. 243-252.

Kasih, Y. (2013). Mewujudkan Pendidikan Kewirausahaan Di Perguruan Tinggi Melalui Proses Pembelajaran yang Berkelanjutan. Jurnal Ilmiah MDP. Vol 2. No. 2 Maret 2013.

Meredith, G. G. (1993). Kewirausahaan Teori dan Praktik, Seri Manajemen No. 97. Jakarta: Pustaka Binaman Pressindo.

Murdjianto \& Wahid, A. (2006). Membangun Karakter dan Kepribadian Kewirausahaan. Yogyakarta : Graha Ilmu

Rencana Strategis UPI 2021-2025

Salim, S. (1995). Kewirausahaan Indonesia Dengan Semangat 17-08-45. Jakarta: Puslatpenkop Departemen Koperasi dan Pembinaan Pengusaha Kecil.

Siswo,W. (2012). Pelaksanaan Pendidikan Kewirausahan di Pendidikan Tinggi. Jurnal Pendidikan dan Kebudayaan. Vol. 18 No. 4 tahun 2012.

United Nations. (2018, September 5). Why the SDGs Matter. Retrieved January 6, 2019. From https://www.un.org/sustainabledevelopment/why-the-sdgs-matter/

United Nations. (2017). Making Global Goals Local Business: A New Era for Responsible $\begin{array}{llll}\text { Business. } & \text { Retrieved January } & 6019 .\end{array}$ From https://www.unglobalcompact.org/library/4321 
United Nations. (2015). Sustainable Development Goals. Retrieved January 6, 2019. From https://sustainabledevelopment.un.org/sdgs

United Nations - Industrial Development Organization. (2015). WEIF 2017 Entrepreneurship and innovation are essential to achieve the Sustainable Development Goals. Retrieved January 6, 2019. From https://www.unido.org/news/weif-2017-entrepreneurship-and-innovation-areessential-achieve-sustainable-development-goals 